Original Research Paper

\title{
Adaptasi Ekonomi Rumah Tangga di Desa Sukowiryo Kabupaten Jember melalui Budidaya Tanaman Sayuran secara Vertikultur
}

\author{
Indri Fariroh $^{1 *}$, Nurul Dwi Novikarumsari ${ }^{2}$, Ratih Apri Utami ${ }^{3}$ \\ ${ }^{1}$ Program Studi Agronomi, Fakultas Pertanian Universitas Jember, Jember, Indonesia; \\ ${ }^{2}$ Program Studi Penyuluhan Pertanian, Fakultas Pertanian Universitas Jember, Jember, Indonesia; \\ ${ }^{3}$ Program Studi Agribisnis, Fakultas Pertanian Universitas Jember, Jember, Indonesia.
}

https://doi.org/10.29303/jpmpi.v3i2.1030

Sitasi: Fariroh, I., Novikarumsari, N. D \& Utami, R. A. (2021). Adaptasi Ekonomi Rumah Tangga di Desa Sukowiryo Kabupaten Jember melalui Budidaya Tanaman Sayuran secara Vertikultur. Jurnal Pengabdian Magister Pendidikan IPA, 4(4)

\section{Article history}

Received: 15 September 2021 Revised: 20 September 2021 Accepted: 30 November 2021

*Corresponding Author: Indri Fariroh, Program Studi Agronomi Fakultas Pertanian Universitas Jember, Jember, Indonesia;

Email: indrifariroh@unej.ac.id

\begin{abstract}
The paddy-paddy-palawija or paddy-paddy-tobacco cropping pattern is generally cultivated by most of members Hidayah Tani group in Sukowiryo Village, Jelbuk district, Jember. Meanwhile vegetables are rarely cultivated in there. Vegetable cultivation in yard around the house using verticulture is one of the household economic adaptation efforts during pandemic for increasing income. The aim of this community service are provide knowledge and insight about alternative uses of yard around the house for vegetable cultivation using verticulture, improve family welfares, and environmentally sustainable agriculture implementation. The method used in this program are preparation, socialization, training, and evaluation approaches. The results of this program showed that the community was enthusiastic in vegetable cultivation using verticulture, because its efficient built on limited yard, easy and simple to built in, could increase household income if its commercialized, supporting family food security, easy to get healty food, verticulture building is easy to move.
\end{abstract}

Keywords: Economic adaptation; Household; Vegetables; Verticulture

\section{Pendahuluan}

$\mathrm{P}$ elatihan budidaya vertikultur di Desa Sukowiryo, Jelbuk, Kabupaten Jember merupakan program pengabdian lanjutan dengan sasaran kelompok Hidayah Tani. Pada program pengabdian sebelumnya, kelompok Hidayah Tani diberikan sosialisasi dan pendampingan tentang budidaya tanaman cabai rawit secara terpadu di lahan pekarangan. Pola tanam padi-padi-palawija atau padi-padi-tembakau umumnya dilakukan oleh sebagian besar anggota kelompok Hidayah Tani, sementara tanaman sayuran belum banyak dibudidayakan di Desa Sukowiryo.

Budidaya sayuran di lahan pekarangan dengan metode vertikultur merupakan salah satu upaya adaptasi bagi ibu-ibu di masa pandemi untuk menambah atau meningkatkan penghasilan. Menurut Ashari et al. (2012), lahan pekarangan umumnya bersifat sambilan atau mengisi waktu luang dan bertujuan untuk memenuhi kebutuhan pangan rumah tangga, pemenuhan gizi, serta sumber pendapatan tambahan bagi rumah tangga petani. Kusumo et al. (2020) menambahkan bahwa budidaya tanaman sayuran di pekarangan dapat mempermudah akses mayarakat dalam mengkonsumsi bahan pangan yang sehat. Pemanfaatan lahan pekarangan untuk kegiatan komersil bisa menggunakan konsep nanosociopreneur, yaitu berangkat dari hal-hal kecil yang bermanfaat besar dalam lingkup yang lebih luas. 
Budidaya tanaman secara vertikultur merupakan teknik bercocok tanam secara vertikal dengan menyusun tanaman secara bertingkat dari bawah ke atas. Metode ini cocok dikembangkan di lahan pekarangan yang terbatas karena tidak membutuhkan lahan yang luas serta media tanam yang banyak. Selain itu, rancangan bangunan vertikultur dapat menambah nilai estetika pekarangan di depan rumah. Menurut Lukman (2011), pertanian vertikultur tidak hanya berfungsi sebagai sumber pangan, namun juga menciptakan suasana alami yang menyenangkan. Model, ukuran, bahan, dan wadah vertikultur sangat beragam, bisa disesuaikan dengan kondisi dan preferensi. Umumnya sistem vertikultur berbentuk persegi panjang, segitiga, berbentuk anak tangga yang berundak-undak, atau berbentuk rak. Bahan membuat vertikultur berupa bambu atau pipa paralon, kaleng bekas, botol bekas, atau lembaran karung beras. Pemanfaatan barang bekas merupakan salah satu filosofi dari pembuatan vertikultur, yaitu memanfaatkan barang-barang tidak pakai yang ada di sekitar tenpat tinggal kita.

Sastro (2009) menjelaskan bahwa sistem vertikultur merupakan solusi bagi masyarakat umum yang berminat dalam budidaya tanaman namun memiliki ruang atau lahan yang terbatas. Kelebihan dari sistem pertanian vertikultur ini adalah efisien dalam penggunaan lahan, lebih hemat dalam penggunaan pupuk dan pestisida, dapat dipindahkan dengan mudah karena tanaman diletakkan di dalam wadah tertentu, serta mudah dalam memonitoring atan memelihara tanaman. Namun demikian, beberapa kelemahan dari sistem budidaya vertikultur adalah investasi awal yang cukup tinggi, serta sistem penyiraman harus kontinyu.

Jenis tanaman yang dapat digunakan dalam sistem budidaya vertikultur adalah tanaman sayuran semusim (sawi, selada, kubis, wortel, tomat, terong, cabai), tanaman bunga (anggrek, mawar, melati, azalea, bunga sepatu), serta tanaman obat-obatan yang sukulen. Media tanam yang umum digunakan adalah campuran top soil, pasir halus atau sekam bakar, pupuk kandang, pupuk hijau dan kapur pertanian. Perbandingan media tanam yang digunakan adalah 50\% tanah : 10\% pasir halus/ sekam bakar : 40\% pupuk kandang/ pupuk hijau/ kompos (Sastro 2009).

Budidaya tanaman secara vertikultur yang diterapkan di Desa Sukowiryo menggunakan teknik dan bahan yang sangat sederhana, sehingga diharapkan menarik minat anggota kelompok Hidayah Tani, terutama ibu-ibu kelompok wanita tani untuk menerapkan di rumah masing-masing sebagai kegiatan tambahan yang produktif. Selain itu, kegiatan ini juga bertujuan untuk memberikan pengetahuan dan wawasan tentang alternatif pemanfaatan lahan pekarangan untuk budidaya sayuran secara vertikultur, meningkatkan taraf kesejahteraan keluarga, serta pertanian berkelanjutan berwawasan lingkungan.

\section{Metode}

\section{Tempat dan Waktu Pelaksanaan}

Kegiatan pengabdian masyarakat ini dilaksanakan di Desa Sukowiryo, Kecamatan Jelbuk, Kabupaten Jember, Provinsi Jawa Timur. Waktu pelaksanaan pengabdian adalah bulan September - Oktober 2021.

\section{Sasaran Pelaksanaan}

Sasaran kegiatan pengabdian ini adalah kelompok Hidayah Tani yang terdiri dari petani dan kelompok wanita tani di Desa Sukowiryo.

\section{Metode Pelaksanaan}

Kegiatan pelaksanaan pengabdian masyarakat ini dilakukan dengan metode sosialisasi dan pelatihan yang sudah disepakati sebelumnya bersama mitra pengabdian. Kegiatan pengabdian terdiri dari beberapa tahap yaitu persiapan, pelaksanaan, dan evaluasi. Deskripsi tahapan kegiatan pengabdian dijabarkan sebagai berikut:

\section{Persiapan}

Tahap persiapan diawali dengan diskusi rencana kegiatan pengabdian lanjutan bersama ketua kelompok Hidayah Tani di Desa Sukowiryo. Setelah terjadi kesepakatan, maka dibuatlah rencana kegiatan pengabdian, serta persiapan alat dan bahan.

\section{Pelaksanaan}

Pelaksanaan program diisi dengan kegiatan sosialisasi materi tentang manfaat menggunakan metode vertikultur dalam budidaya sayuran di lahan pekarangan, pengenalan media tanam dan jenis sayuran yang digunakan untuk vertikultur, pembibitan, pemeliharaan, serta praktik pembuatan vertikultur sederhana.

\section{Evaluasi}

Evaluasi kegiatan pengabdian dilaksanakan secara langsung setelah sosialisasi dan praktik pembuatan vertikultur sederhana selesai dilakukan. 
Evaluasi dilakukan dalam bentuk interview langsung, diskusi tentang kegiatan yang sudah dilakukan kepada anggota kelompok Hidayah Tani, serta refleksi bagi tim pelaksana.

\section{Hasil dan Pembahasan}

Pengabdian ini merupakan upaya yang dilakukan untuk memberikan pengetahuan dan keterampilan tentang budidaya vertikultur di lahan pekarangan kepada petani (kelompok tani dan wanita tani). Kegiatan pengabdian di awali dengan sosialisasi pengetahuan tentang teknik budidaya vertikultur secara sederhana dari bambu dan pipa paralon sebagai dasar bangunannya. Sastro (2009) menyatakan bahwa bahan yang dapat digunakan untuk membuat rak vertikultur adalah kayu, bambu, pipa paralon, pot, kantong plastik, atau gerabah. Sedangkan bentuk bangunan vertikultur dapat dimodifikasi menurut kreativitas dan lahan yang tersedia. Penentuan bangunan vertikultur dilakukan berdasarkan karakteristik tanaman yang ingin dibudidayakan.

Selain bahan pembuatan vertikultur, petani juga diberikan pemahaman tentang jenis tanaman apa saja yang bisa digunakan dalam budidaya vertikultur. Benih sayuran yang digunakan oleh petani selama kegiatan adalah sawi dan kangkung. Sarkono et al. (2020) menjelaskan bahwa, jenis tanaman yang akan ditanam dalam budidaya vertikultur mempengaruhi wadah yang akan digunakan. Pada budidaya vertikultur menggunakan wadah talang, bambu atau paralon yang dipasang secara horizontal, kurang cocok untuk sayuran jenis buah seperti cabai, terong, tomat, buncis, pare, dan lainnya. Hal ini disebabkan karena wadah yang dangkal sehingga akar tanaman tidak cukup kuat untuk menopang tanaman tumbuh dengan tegak. Sayuran buah cocok ditanam di dalam pot, polybag, paralon, dan bambu yang dipasang vertikal karena bisa menampung media tanam yang lebih banyak.

Petani juga mendapatkan informasi tentang bagaimana cara menyemai benih sayuran, kapan bibit bisa dipindah tanam, media tanam yang bisa digunakan, serta pemeliharaan rutin seperti pemberian pupuk, pengendalian OPT (organisme pengganggu tanaman) pada tanaman, dan cara penyiraman (Gambar 1).

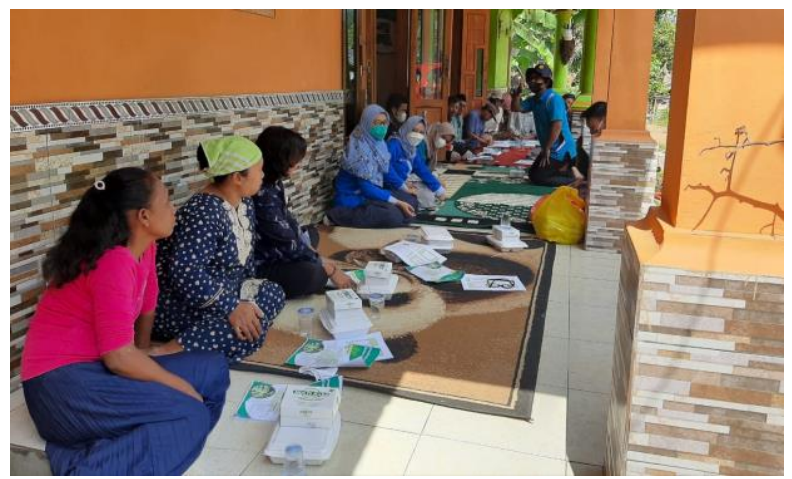

Gambar 1. Sosialisasi Budidaya Vertikultur

Bangunan vertikultur yang dikenalkan kepada petani berupa rak berbentuk persegi panjang bertingkat yang disusun dari bambu dan pipa paralon tunggal yang disemen di timba. Praktik pembuatan bangunan vertikultur dilakukan secara langsung di lahan pekarangan salah satu anggota kelompok tani (Gambar 2). Hal ini memudahkan petani jika ada masalah yang ingin ditanyakan secara langsung kepada pemateri.

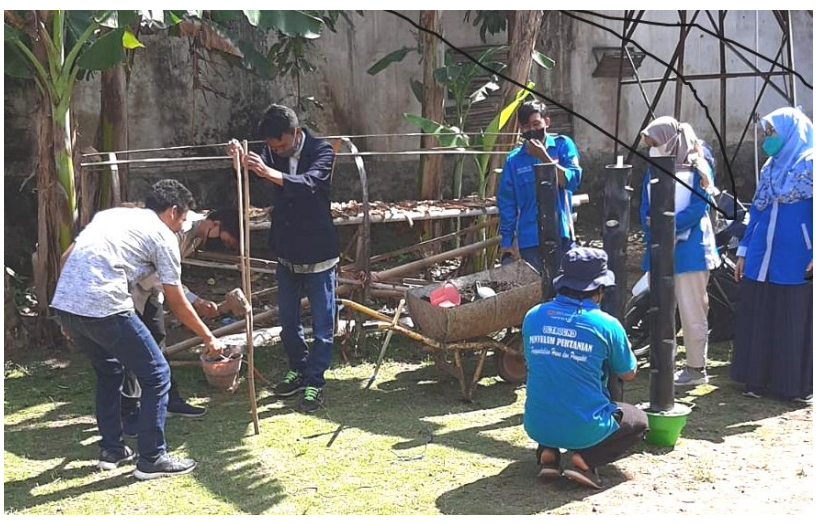

Gambar 2. Praktik Pembuatan Bangunan Vertikultur

Bangunan vertikultur berbentuk rak mempunyai dimensi tinggi $1 \mathrm{~m}$, lebar $1 \mathrm{~m}$, dan panjang $2 \mathrm{~m}$. Batang bambu sepanjang $2 \mathrm{~m}$ yang digunakan untuk media tanam kemudian dilubangi bagian atasnya untuk menanam, sementara bagian bawah bambu dilubangi menggunakan bor atau pisau untuk sirkulasi air agar tidak menggenang. Batang bambu yang dipilih diusahakan ujung kanan dan kirinya tertutup sekat bambu supaya media tanam tidak tercecer. Batang bambu yang sudah dilubangi kemudian disusun di rak bangunan vertikultur dan diikat ujung-ujungnya menggunakan tali rami.

Bangunan vertikultur dari pipa paralon tunggal mempunyai lubang sebanyak \pm 14 buah 
dalam satu pipa. Bagian bawah pipa dilekatkan dengan semen di ember supaya bangunan bisa tegak berdiri. Bagian tengah pipa paralon, dipasang pipa pvc 0.5 inch yang berfungsi sebagai saluran air seperti irigasi tetes. Media tanam kemudian diisikan dari atas ke bawah hingga lubang tanam di samping pipa terisi dan menjadi siap ditanami (Gambar 3). Media tanam yang digunakan pada sistem rak dan paralon tunggal adalah campuran antara tanah, arang sekam, dan pupuk organik padat. Menurut Sastro (2009), media tanam yang disarankan untuk budidaya vertikultur adalah arang sekam bakar/ pakis yang dicampur dengan pupuk organik padat berbentuk pelet/ granul. Sarkono et al. (2020) menambahkan bahwa media tanam yang digunakan dalam budidaya vertikultur bisa berasal dari bahanbahan yang tersedia di sekitar dusun Penimbung Barat seperti tanah kebun, pupuk kandang, dan limbah gergajian kayu. Kusumo et al. (2020) juga menggunakan bahan baku yang tersedia di sekitar kelurahan Antapani Kidul seperti tanah merah yang diberi bahan organik, arang sekam, serta kompos sebagai media tanam dalam praktik budidaya tanaman sayur menggunakan sistem vertikultur. Media tanam untuk vertikultur juga sebaiknya tidak terlalu padat.

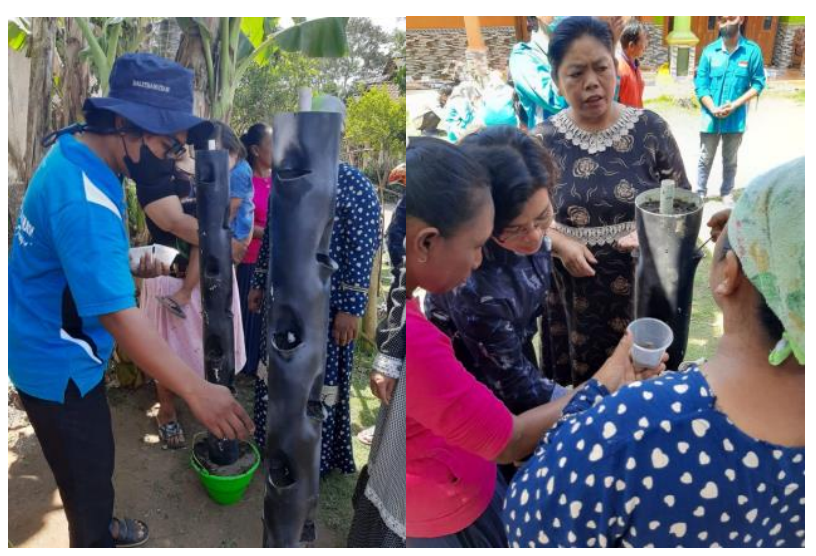

Gambar 3. Pengenalan Bangunan Vertikultur dari Pipa Paralon Tunggal

Praktik pembibitan tidak dilaksanakan dalam pengabdian ini, namun materi tentang pembibitan/ penyemaian benih sayuran sudah disosialisasikan di awal. Benih sayuran yang ditanam pada rak bertingkat adalah benih sawi, sementara pada pipa paralon ditanam benih kangkung. Diwanti (2018) menjelaskan bahwa umumnya pembibitan dilakukan pada nampan atau wadah plastik yang sudah dilubangi untuk mengeluarkan kelebihan air. Media tanam yang digunakan di pembibitan adalah tanah, arang sekam dan pupuk kandang. Menurut Lukman (2011), persemaian bisa dilakukan menggunakan tray dengan 128 buah lubang, pot berukuran sedang, atau wadah bekas kue. Benih yang sudah disemai dapat dipindah setelah 2 atau 3 minggu tanam yang ditandai dengan munculnya 3-4 daun. Bibit yang sudah mengeluarkan 4-5 daun lebih ideal untuk dipindahkan. Sebelum bibit dipindahkan, media tanam di vertikultur disiram terlebih dahulu hingga jenuh, yang ditandai dengan menetesnya air dari lubang tanam. Semua bagian akar dari bibit harus dibenamkan ke media tanam.

Salah satu campuran media tanam yang digunakan pada kedua jenis bangunan vertikultur adalah pupuk organik padat, sehingga pemberian pupuk kimia tidak perlu diaplikasikan. Menurut Lukman (2011), pada budidaya sayuran secara vertikultur sebaiknya menggunakan pupuk organik seperti pupuk kompos, pupuk kandang, atau bokashi. Pemberian pupuk kimia hanya jika diperlukan saja. Sayuran buah seperti cabai dan tomat bisa ditambahkan satu sendok teh $\mathrm{KCl}$ untuk mencegah kerontokan pada buah setiap 5-6 bulan sekali. Selain itu, limbah dapur atau daun kering juga bisa dimanfaatkan untuk pembuatan pupuk bokashi.

Praktik pengendalian OPT tidak bisa dilakukan secara langsung, namun petani diberi pemahaman bahwa pengendalian OPT hanya dilakukan seperlunya saja ketika ada hama atau penyakit yang menyerang tanaman. Selain itu, pengendalian OPT ditekankan kepada petani untuk dilakukan secara mekanik, yaitu dengan mengutip atau mengambil hama secara langsung dengan tangan. Penggunaan bahan kimia harus dihindari dalam budidaya sayuran secara vertikultur, karena budidaya secara organik lebih tepat diterapkan untuk budidaya skala rumah tangga. Bangunan vertikultur juga disarankan terkena sinar matahari supaya tidak terserang jamur penyebab penyakit. Menurut Hidayati et al. (2018), tempat terbuka penting dalam peletakan bangunan vertikultur supaya tanaman sayuran mendapatkan cahaya matahari yang cukup. Jika ada gulma yang mengganggu maka perlu dilakukan penyiangan dan kondisi tanaman perlu diperiksa setiap hari untuk memantau serangan OPT pada tanaman.

Penyiraman tanaman pada rak vertikultur bertingkat dilakukan setiap pagi dan sore dengan 
sprayer yang diatur volume airnya supaya tidak terlalu besar. Penyiraman tanaman pada pipa paralon tunggal dilakukan menggunakan corong air yang dipasangkan di atas pipa pvc kecil berukuran diameter 0.5 inch pada pagi dan sore hari. Pipa pvc kecil berfungsi menyebarkan air ke tiap lubang tanam secara merata. Hidayati et al (2018) menjelaskan bahwa penyiraman pada budidaya sayuran dengan sistem vertikultur harus dilakukan secara rutin, minimal sehari sekali. Penyiraman dilakukan menggunakan semprotan/hand sprayer yang berlubang kecil agar air siraman yang keluar tidak terlalu deras.

Evaluasi dilakukan secara langsung setelah kegiatan selesai dilaksanakan. Berdasarkan hasil diskusi kelompok, anggota kelompok Hidayah Tani menunjukkan respon yang antusias dengan adanya kegiatan pelatihan budidaya sayuran menggunakan sistem vertikultur. Peserta pelatihan sangat tertarik dengan materi dan pengetahuan tentang sistem vertikultur, sehingga mempunyai keinginan untuk mencoba membuat dan mengaplikasikan materi yang sudah disampaikan. Khususnya kelompok wanita tani yang terdiri dari ibu-ibu petani menunjukkan antusias yang lebih tinggi sejak awal mulai dari materi hingga praktik pembuatan bangunan vertikultur.

Kelompok tani dan wanita tani di Desa Sukowiryo memberikan respon positif terhadap sistem vertikultur, sehingga dalam pelaksanaan kegiatan pengabdian ini sasaran memperhatikan dengan baik materi yang disampaikan. Diskusi dan demonstrasi interaktif juga dilakukan petani selama pelatihan membuat bangunan vertikultur. Menurut anggota kelompok tani, sistem vertikultur dapat mempermudah teknis penanaman. Selain itu, sistem vertikultur sangat efisien diterapkan di lahan pekarangan yang sempit, menambah pendapatan keluarga jika dikomersilkan, serta dapat mendukung ketahanan pangan di lingkup keluarga. Kegiatan pengabdian yang telah terlaksana diharapkan dapat terus bersinergi sehingga masyarakat menjadi lebih mandiri baik petani maupun keluarganya.

\section{Kesimpulan}

Budidaya tanaman sayuran menggunakan sistem vertikultur menjadi salah satu solusi dalam upaya adaptasi bagi ibu-ibu di masa pandemi untuk menambah atau meningkatkan penghasilan.
Kelebihan dari budidaya sayuran secara vertikultur ini adalah:

1. Proses pembuatannya mudah dan sederhana, yaitu dengan memanfaatkan bahan baku yang ada di sekitar tempat tinggal

2. Sangat efisien diterapkan di lahan pekarangan yang terbatas

3. Menambah penghasilan rumah tangga jika kegiatannya dikomersilkan

4. Mendukung ketahanan pangan keluarga

5. Memudahkan dalam mendapatkan bahan makanan yang sehat karena umumnya dilakukan secara organik

6. Bangunan vertikultur mudah dipindahkan karena tidak permanen

Kelemahan dari sistem ini adalah sistem penyiraman harus teratur supaya tanaman tidak layu.

\section{Ucapan Terima Kasih}

Tim menyampaikan terima kasih kepada LP2M Universitas Jember atas pemberian bantuan dana stimulus tahun anggaran 2021 dalam melaksanakan pengabdian masyarakat di Desa Sukowiryo, Jelbuk, Jember.

\section{Daftar Pustaka}

Ashari, Saptana, dan Purwantini, T.B. 2012. Potensi dan Prospek Pemanfataan Lahan Pekarangan untuk Mendukung Ketahanan Pangan. Forum Penelitian Agro Ekonomi, Vol 30, No 1, hal 13-30.

Diwanti, D.P. 2018. Pemanfaatan Pertanian Rumah Tangga (Pekarangan Rumah) dengan Teknik Budidaya Tanaman Sayuran secara Vertikultur. MARTABE: Jurnal Pengabdian Masyarakat, Vol 1, No 3, hal 101-107.

Hidayati, N., Rosawanti, P., Arfianto, F., dan

Hanafi, N. 2018. Pemanfaatan Lahan

Sempit untuk Budidaya Sayuran dengan Sistem Vertikultur. PengabdianMu, Vol 3, No 1, hal 40-46.

Kusumo, R.A.B., Sukayat, Y., Heryanto, M.A., dan Wiyono, S.N. 2020. Budidaya Sayuran dengan Teknik Vertikultur untuk Meningkatkan Ketahanan Pangan Rumah Tangga di Perkotaan. Dharmakarya: Jurnal Aplikasi Ipteks untuk Masyarakat, Vol 9, No 2, hal 89-92. 
Lukman, L. 2011. Teknologi Budidaya Tanaman Sayuran secara Vertikultur. https://www.litbang.pertanian.go.id/infoaktual/918/file/verikultur.pdf diakses tgl 9 Oktober 2021.

Sarkono, Hidayati, E., Suryadi, B.F., dan Tresnani, G. 2020. Pelatihan Budidaya Tanaman Sayuran secara Vertikultur Menuju Terbentuknya Kawasan Rumah Pangan Lestari di Desa Penimbung Lombok Barat. Prosiding PEPADU 2020, Seminar Nasional Pengabdian kepada Masyarakat Tahun 2020, LPPM Universitas Mataram, Vol 2, hal 304-310. Mataram. 2-3 Desember 2020.

Sastro, Y. 2009. Budidaya Tanaman Organik secara Vertikultur. Balai Pengkajian Teknologi Pertanian: Jakarta. 